FIU Law Review

Spring 2010

\title{
A New Board Policy on Deferral to Arbitration: Acknowledging and Delimiting Union Waiver of Employee Statutory Rights
}

Michael C. Harper

Boston University School of law

Follow this and additional works at: https://ecollections.law.fiu.edu/lawreview

Part of the Other Law Commons

Online ISSN: 2643-7759

\section{Recommended Citation}

Michael C. Harper, A New Board Policy on Deferral to Arbitration: Acknowledging and Delimiting Union Waiver of Employee Statutory Rights, 5 FIU L. Rev. 685 (2010).

DOI: https://dx.doi.org/10.25148/lawrev.5.2.18

This Article is brought to you for free and open access by eCollections. It has been accepted for inclusion in FIU Law Review by an authorized editor of eCollections. For more information, please contact lisdavis@fiu.edu. 


\title{
A New Board Policy on Deferral to Arbitration: Acknowledging and Delimiting Union Waiver of Employee Statutory Rights
}

\author{
Michael C. Harper*
}

\section{INTRODUCTION}

In late 2009, the Office of the General Counsel of the National Labor Relations Board (NLRB) published an Operations-Management Memorandum (O-M Memorandum) ${ }^{1}$ advising regional directors and other Board officers that "a new approach to cases involving arbitral deference may be warranted." ${ }^{2}$ The Memorandum indicated a new approach might be guided by the Supreme Court's decision in 14 Penn Plaza, LLC v. Pyett, ${ }^{3}$ and a separate older line of decisions in the District of Columbia Circuit Court of Appeals. $^{4}$ The O-M Memorandum noted the District of Columbia Circuit decisions had advanced a theory of implied contractual waiver to require complete Board deference to the arbitration process in most cases. It then compared this implied waiver theory with the Penn Plaza Court's requirement that any union waiver of an employee's access to a judicial forum for statutory claims must be expressed in "clear and unmistakable" terms. ${ }^{5}$ The Memorandum also contrasted both of these waiver standards with the "Spielberg/Olin standards" the Board currently uses to determine whether to defer its resolution of unfair labor practice claims to an arbitrator's completed resolution of contractual claims. ${ }^{6}$ The Memorandum concluded by

\footnotetext{
* Michael C. Harper is Professor of Law and Barreca Labor Relations Scholar at Boston University School of Law.

1 Office of the General Counsel, Division of Operations-Management, Memorandum OM 10-13 (CH), Nov. 3, 2009 [hereinafter O-M Memorandum].

Id. at 2 .

129 S. Ct. 1456 (2009).

4 The O-M Memorandum cited Plumbers \& Pipefitter Local Union No. 520 v. NLRB, 955 F.2d 744 (D.C. Cir. 1992), and Titanium Metals Corp. v. NLRB, 392 F.3d 439 (D.C. Cir. 2004). O-M Memorandum, supra note 1 , at 1 .

5 O-M Memorandum, supra note 1, at 1 (citing 14 Penn Plaza, 129 S. Ct. at 1465 (citing Wright v. Universal Mar. Serv. Corp., 525 U.S. 70, 80 (1998))).

6 These standards, as stated in the Memorandum, are:

whether (1) the arbitration proceedings were fair and regular; (2) all parties agreed to be bound; (3) the Arbitrator "considered" the unfair labor practice issue in that the contractual issue is "factually parallel" to the unfair labor practice issue and the arbitrator was presented generally with the facts
} 
requesting the submission to the Division of Advice "all cases in which a Region recommends that the General Counsel reject deference."7

The General Counsel should be commended for this reconsideration of the Board's standards for deferring to arbitration in the light of evolving judicial standards for the waiver of statutory rights through arbitration. As I argued almost thirty years ago, ${ }^{8}$ based in part on Chairman Murphy's determinative decision in General American Transportation, ${ }^{9}$ any Board deferral of statutory claims to the arbitration process entails an at least partial compromise of the protection of statutory rights and thus should be conditioned on the union having legitimately waived that protection through acceptance of arbitration. ${ }^{10}$ The Board, I argued, thus should not defer to arbitration the protection of any substantive statutory right that could not be waived by an exclusive bargaining agent under the reasoning of the Court's decision in NLRB v. Magnavox Co. ${ }^{11}$ The current reconside-

relevant to resolving the unfair labor practice charge and (4) the resulting decision is not "clearly repugnant" to the Act.

O-M Memorandum, supra note 1, at 1 n.1 (citing Olin Corp., 268 N.L.R.B. 573, 573-74 (1984) (citing and clarifying Spielberg Mfg. Co., 112 N.L.R.B. 1080 (1955))).

7 O-M Memorandum, supra note 1, at 2.

8 See Michael C. Harper, Union Waiver of Employee Rights Under the NLRA: Part II, A Fresh Approach to Board Deferral to Arbitration, 4 InDUS. REL. L.J. 680 (1981).

9228 N.L.R.B. 808, 810 (1977). In General American Transportation, based on Chairman Murphy's swing-vote opinion, the Board decided it would no longer require the use of unused, but available arbitration processes in cases charging violations of $\S \S 8(\mathrm{a})(1), 8(\mathrm{a})(3), 8(\mathrm{~b})(1)(\mathrm{A})$, and 8(b)(2) of the NLRA. Id. at 812-13. Chairman Murphy argued these sections protect the non-waivable $\S 7$ rights of individual employees. Id. She stated that deferral to future arbitration should be confined to charges of violations of $\S \S 8(\mathrm{a})(5)$ and $8(\mathrm{~b})(3)$, which Chairman Murphy asserted involve disputes between unions and employers about the meaning of collective agreements. Id. at 810-11. Chairman Murphy did not apply her distinction to Board deference to completed arbitration processes, id. at 813, the subject of the O-M Memorandum, and the Board never applied the distinction to post-arbitration deference in later cases.

10 See Harper, supra note 8, at 684-87. Unlike Chairman Murphy, see supra note 9, I argued that the distinction between $\S 7$ rights legitimately waived by a collective representative and those not so waived should be applied to Board doctrine on post-arbitration deference as well as to Board doctrine on pre-arbitration deferral. See Harper, supra note 8, at 687-90. I also explained why Chairman Murphy's distinction between types of unfair labor practice charges did not fully track the distinction between $\S 7$ rights subject to union waiver and those outside the authority of unions. See id. at 690-91.

11415 U.S. 322, 324-25 (1974) (holding that company rule against distribution of literature on company property, including non-work areas, denied $\S 7$ rights if enforced against distributions in support of, as well as against the union representative, despite possible authorization of rule in collective bargaining agreement). The Court in Magnavox distinguished $\S 7$ "rights in the economic area", such as the right to strike to obtain better terms and conditions of employment, which can be waived "during the time of the agreement as [a] quid pro quo" for employer concessions, from the "rights of the employees to exercise their choice of a bargaining representative . . to have no bargaining representative, or to retain the present one, or to obtain a new one," where "a different rule" regarding waiver should obtain. 415 U.S. at 325-26. In the first part of my article on the implications of the Magnavox decision, Michael C. Harper, Union Waiver of Employee Rights Under the NLRA: Part I, 4 INDUS. REL. L.J. 335 (1981), I elaborated a comprehensive definition of the latter set of rights to include rights: 
ration of the relevance of waiver offers the promise of reopening the path for setting limits on deferral marked by Chairman Murphy, but foreclosed by the hardening of Board deferral doctrine for post-arbitration deference in Olin Corp. ${ }^{12}$ and for pre-arbitration deferral in United Technologies Corp. ${ }^{13}$

The General Counsel's reconsideration of the Board's deference standards in light of Penn Plaza and the District of Columbia Circuit decisions, however, also poses the risk that the Board may attempt to respond to both by merging the Penn Plaza standard for union waiver of a represented employee's procedural right to a judicial forum to assert a statutory claim with a standard for union waiver of represented employees' substantive statutory rights. Such a merger, if it failed to distinguish between waivable and non-waivable substantive $\S 7$ rights, could result in a greater compromise of employee statutory rights not under the authority of exclusive bargaining agents. The General Counsel and the Board can avert such a compromise only by understanding both the appropriate limits that must be placed on the District of Columbia Circuit's theory of implied waiver of substantive $\S 7$ rights under the National Labor Relations Act ${ }^{14}$ (NLRA) and the limited relevance to the NLRA of the Penn Plaza Court's treatment of union waiver of a procedural statutory right to a judicial private right of action. Such understanding in turn could lead to a new formulation of Board doctrine on deferral to arbitration that not only is responsive to the District of Columbia Circuit decisions and consistent with Penn Plaza's support of arbitration under collective agreements, but also achieves Chairman Murphy's goal of providing full protection to $\S 7$ rights not subject to union waiver.

to communicate with each other concerning the identity and strategies of their bargaining agent, to communicate with their employer concerning the identity of their bargaining agent, to associate with, lead or support a bargaining agent, to act to achieve employer recognition and acceptance of a bargaining agent, to act to obtain better terms and conditions of employment from sources outside a bargaining relationship, to assist individuals outside the protected employees' bargaining unit, and to act to protect and rectify the denial of other non-waivable rights.

See Harper, supra note 8, at 680 n.4.

12268 N.L.R.B. 573 (1984). In Olin, the Board both confirmed its policy under Spielberg Mfg. Co., 112 N.L.R.B. 1080 (1955), to defer to arbitration awards when certain conditions are met and also restated what those conditions required. 268 N.L.R.B. at 573-74. That restatement is set forth in the OM Memorandum. See supra note 1.

13268 N.L.R.B. 557 (1984). The Board's decision in United Technologies expressly rejected Chairman Murphy's insulation of charges under $\S \S 8(\mathrm{a})(1), 8(\mathrm{a})(3), 8(\mathrm{~b})(1)(\mathrm{A})$ and $8(\mathrm{~b})(2)$ from prearbitration deferral. Id. at 559-60. As noted in supra note 9, neither Chairman Murphy in General American Transportation or the Board in later cases, had proceeded further to apply the distinction in post-arbitration deference cases, the subject of the O-M Memorandum.

1429 U.S.C. $§ 151(2006)$. 
This essay provides such a new formulation. Part II of the essay explains the theory of implied union waiver of substantive $\S 7$ rights in favor of contractual rights as advanced by the District of Columbia Circuit Court of Appeals under the leadership of Judge Harry Edwards. ${ }^{15}$ This Part also articulates a reformulation of Board deferral doctrine for waivable substantive $\S 7$ rights. ${ }^{16}$ Since this reformulation is based on placing appropriate limits on Judge Edwards's theory, it somewhat modifies the tests he sets forth in the decisions cited in the O-M Memorandum. Part III explains the Penn Plaza decision and its relevance to Board deferral to arbitration in cases involving $\S 7$ rights that are not subject to waiver by exclusive bargaining agents. ${ }^{17}$ Part III also explains why the Board, as an executive agency serving a public function, while not required to set aside its processes for a private arbitration process chosen by either a union or the employees it represents, nonetheless might draw on the process even in the discharge of its responsibility to protect those $\S 7$ rights that are not subject to the authority of exclusive bargaining representatives. ${ }^{18}$

\section{THE WAIVER OF SUBSTANTIVE RIGHTS THROUGH ARBITRATION}

\section{A. Judge Edwards's Waiver Theory}

A few years after my own elaboration of Chairman Murphy's treatment of Board deferral to arbitration as an acceptance of union waiver of employee rights, Judge Harry Edwards of the District of Columbia Circuit developed in a law review article his own waiver-based theory of why the Board not only may, but also must, defer the resolution of most unfair labor practice charges to the resolution of parallel contractual claims in the arbitration process. ${ }^{19}$ Judge Edwards argued that a collective bargaining agreement, at least when it includes an agreement to arbitrate disputes, defines the reach of many, if not most, $\S 7$ rights of represented employees during the term of the agreement:

I believe that when the parties negotiate a collective bargaining agreement and stipulate that they will arbitrate disputes arising under it, they have waived many of their statutory rights under the NLRA.

\footnotetext{
See infra text accompanying notes 19-61.

See infra text accompanying notes 62-92.

See infra text accompanying notes 93-113.

See infra text accompanying notes 114-128.

19 See Harry T. Edwards, Deferral to Arbitration and Waiver of the Duty to Bargain: A Possible Way Out of Everlasting Confusion at the NLRB, 46 OHIO ST. L.J. 23 (1985).
} 
The parties' agreement, in essence, supplants the statute as the source of many employee rights in the context of collective bargaining. ${ }^{20}$

The parties' commitment of the interpretation of the meaning of an agreement to arbitration thus is a delegation of the protection of the rights subject to the control of the union as the representative of the employees. For Judge Edwards, the Board has no authority to reject a negotiated arbitration process as the means to define and protect waivable employee rights. Judge Edwards concludes that the Board must accept the results of any negotiated arbitration process unless the contract provision as interpreted sacrifices some non-waivable right of employees, including the right to fair representation, or is otherwise "illegal."

Note that Judge Edwards's theory has two premises: first, that a union has the authority to delegate the protection of the $\S 7$ rights it controls to an arbitration process; and second, that a union does so whenever it negotiates a collective bargaining agreement that establishes an arbitration process. The first premise is not problematic. Assuming that a union has authority to waive the substance of a particular $\S 7$ right, such as the right to strike or the right to negotiate over a particular topic during the term of an agreement, the union should be able to subject the right to any substantive or procedural qualification effected by arbitration. Inasmuch as arbitration is a continuation of the collective bargaining process, any such qualification is no more than an acceptable partial waiver of a right that could be totally bargained away.

The second premise of Judge Edwards's theory is more open to challenge, however. Such a challenge might seem to be supported by the Court's clear pronouncement in Metropolitan Edison Co. v. NLRB, ${ }^{22}$ less than two years before the publication of Judge Edwards's article, that it would "not infer from a general contractual provision that the parties intended to waive a statutorily protected right unless the undertaking is "explicitly stated.",23 More succinctly, the waiver must be "clear and unmistakable." $"$ The negotiation of an arbitration clause in itself does not seem to be a "clear and unmistakable" waiver of a substantive right.

Judge Edwards's theory nonetheless may be consistent with Metropolitan Edison and the requirement that any waiver of a statutory right be clear and unmistakable. The negotiation of an arbitration process in a collective bargaining agreement generally is a clear and unmistakable

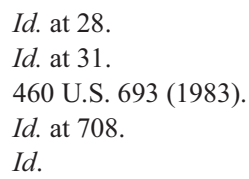


statement that the agreement is to be definitively interpreted through that process. If the process then offers a clear and unmistakable interpretation that qualifies a substantively waivable statutory right, the Metropolitan Edison standard can be met, even if the agreement itself would not be read by the Board or a court to express a clear and unmistakable waiver.

In Metropolitan Edison itself, the Court rejected the employer's argument that the bargaining representative, by negotiating a new collective agreement without changing a general no-strike clause as interpreted in two prior arbitration decisions, had waived union officials' waivable statutory right not "to take affirmative steps to end unlawful work stoppages." The Court stated that "inconsistent, sporadic, or ambiguous" past arbitration decisions do not provide a clear waiver. ${ }^{26}$ The Court also suggested, however, that a past arbitration that "itself clearly and unmistakably imposes an explicit duty on union officials to end work stoppages" could do so. ${ }^{27}$ This suggestion seems to confirm that a decision rendered in the arbitration process, as the continuation of collective bargaining, can qualify a waivable statutory right, regardless of whether the collective agreement itself would be read by the Board or by a court to express a clear and unmistakable waiver. As stated by Judge Edwards's article, Metropolitan Edison "can be read as endorsing the view that where the parties provide for final and binding arbitration of their disputes, the arbitrator's decision becomes part of the written contract, and that contract, as construed by the arbitrator, can waive rights otherwise provided by the statute." 28

Under Judge Edwards's theory, what should be required for an arbitration process to be a clear and unmistakable waiver of a statutory right? Met-

25 Id. at 707. The Court's determination that the statutory right affected in Metropolitan Edison was substantively waivable by the collective representative, in my view, was in tension with the Court's prior decision in NLRB v. Magnavox Co., 415 U.S. 322 (1974), to insulate from union waiver the $\S 7$ right to solicit other employees in support of a collective representative. The Magnavox Court found the latter right not to be waivable because it concerns the employees' choice of collective bargaining representative, rather than the "economic" right to use concerted action to extract better terms and conditions from the employer. 415 U.S. at 325 ; see also supra note 11 . The $\$ 7$ right penalized by imposing a duty on union officials to take affirmative steps to end an unlawful strike also concerns the employees' choice of collective bargaining representative, however, because penalizing union officials for doing no more than other employees penalizes the right to choose to be a union official and thereby discourages at least particular kinds of union leaders. The Court in Metropolitan Edison, however, viewed a union's agreement to impose special strike control duties on their own officials as "more closely related to the economic decision a union makes when it waives its members' right to strike." 460 U.S. at 706; see also Local 900, Int'1 Union of Elec., Radio \& Mach. Workers v. NLRB, 727 F.2d 1184, 1190 (D.C. Cir. 1984) (interpreting Metropolitan Edison to uphold "discriminatory measures as necessary for the enforcement of the unions' lawful waivers of the economic right to strike").

26460 U.S. at 709.

27 Id. at 709 n. 13.

28 Edwards, supra note 19, at 38. 
ropolitan Edison was a review of a Board unfair labor practice finding, not a review of a Board decision to defer or not to defer to an arbitration award in the particular case. The Court considered past arbitration decisions only in light of the employer's argument about the meaning of a subsequent bargaining agreement. If an arbitrator had found in the particular case that the general no-strike clause in the collective agreement imposed an affirmative duty on union officials to avoid strikes in breach of that clause, however, under Judge Edwards's theory that finding would be a clear and unmistakable waiver. It would be clear and unmistakable, moreover, regardless of the ambiguity of the contractual language and of other evidence of an agreement to waive the union officials' $\S 7$ rights on which the arbitrator rested. The meaning of the arbitrator's decision has to be clear, not the underlying basis for the decision. $^{29}$

The two District of Columbia Circuit Court of Appeals decisions cited in the O-M Memorandum, ${ }^{30}$ both authored by Judge Edwards, underscore that his theory requires only that the result of the arbitration process, not the collective bargaining agreement itself, be clear to the Board. In neither case did Judge Edwards examine the underlying collective agreement to determine whether there had been a clear and unmistakable waiver of the $\S 7$ right on which the unfair labor practice charge was based. The opinion in each case considered only whether a pre-arbitration settlement agreement, reached between the union and employer in accordance with fair and regular processes established by the collective agreement, had effectively waived any statutory rights, not whether the underlying collective agreements had clearly done so. Furthermore, in each case Judge Edwards assumed, even in the absence of any language concerning statutory rights in the settlement agreement, that the settlement of a contractual grievance against a termination without cause also had waived, or at least merged into the contractual right, any $\S 7$ right affected by the termination.

29 Judge Edwards indeed relied in his article on a panel decision involving an employer's enhanced discipline of a union official for participating in waivable protected action. See Fournelle v. NLRB, 670 F.2d 331 (D.C. Cir. 1982). In Fournelle, Judge Edwards had held that the Board in determining whether the union had waived the official's statutory protection had to defer to an arbitrator's interpretation of the collective bargaining agreement in resolving an earlier grievance. Id. at 338. In his article, Judge Edwards distinguished the Court's subsequent decision in Metropolitan Edison by stressing that in Fournelle, unlike in Metropolitan Edison, the prior arbitration award had "explicitly" imposed extra duties on union officials to avoid unlawful work stoppages and that there also was no ambiguity about the relevance of the award to future disciplinary actions. See Edwards, supra note 19, at 38. In his article Judge Edwards, in my view justifiably, also criticized a Board decision, John Morrell \& Co., 270 N.L.R.B. 1 (1984), that had interpreted Metropolitan Edison to require that there "be explicit language in the contract itself (as opposed to an arbitrator's explicit construction of the contract) to support a waiver." Edwards, supra note 19, at 39.

$30 \quad$ See supra note 4. 
In the first case, Plumbers and Pipefitters Local Union No. $529 v$. $N L R B,{ }^{31}$ Judge Edwards elaborated on how his waiver theory should be applied to require Board deference to the arbitration process. In this case, the court upheld the Board's deference to a settlement of a grievance filed by an employee who had been discharged for following the instructions of a union business manager to advise other employees to ignore a foreman's shift assignment instructions as a protest of the loss of bargaining unit work. ${ }^{32}$ Judge Edwards held the Board had reasonably applied its own standards for deferring to arbitration settlements, which generally track the Spielberg/Olin standards for giving deference to arbitration decisions, including a requirement that the decision not be "palpably wrong." ${ }^{33} \mathrm{He}$ also asserted, however, that since the statutory right "implicated" in the grievance, the right to take concerted action in protest of an employer's decision regarding work, was "waivable," "it is unclear why the Board would ever have any choice but to give deference, at least so long as the grievance procedures through which the settlement is reached are fair and regular and the union has not breached its duty of fair representation.",34 Judge Edwards assumed that the settlement of the grievance charging unfair treatment by the employer, as a fair and regular outcome of an established arbitration process, constituted a clear statement of the extent to which the union authorized the employer to control the grievant, including in his exercise of the waivable $\S 7$ right to induce an economic strike. Such a statement, in Judge Edwards's view, cannot be a "palpably wrong" of statutory law because it itself expresses the union's agreement to qualify an employee right within its authority. ${ }^{36}$

31955 F.2d 744 (1992).

32 Id. at $747,755$.

33 See supra note 6. The "palpably wrong" standard was adopted in NLRB v. Olin Corp. 268 N.L.R.B. 573, 574 (1985), as an explanation of the meaning of the "clearly repugnant to the Act" standard enunciated in Spielberg. As Judge Edwards noted in Plumbers and Pipefitters, the Board in Alpha Beta Co., 273 N.L.R.B. 1546 (1985), and U.S. Postal Service, 300 N.L.R.B. 196 (1990), adapted the Spielberg/Olin standards for deference to settlement agreements. See 955 F.2d at 749-50.

$34 \quad 955$ F.2d at 756.

35 As Judge Edwards noted in Plumbers and Pipefitters, in Alpha Beta and U.S. Postal Service the Board stated that a settlement will not be deemed "palpably wrong" if it was arrived at through a process in which both sides made concessions. Id.; see also supra note 33. It is difficult to understand the relevance of concessions to the suitability of deference to the arbitration process, however. This factor certainly "makes no sense if the underlying theory of the Board's deference policy is the contractual waiver doctrine. ..." 955 F.2d at 756.

36 The second District of Columbia Circuit Court of Appeals case cited in the O-M Memorandum, Titanium Metals Corp. v. NLRB, 392 F.3d 439 (D.C. Cir. 2004), also involved the question of whether the Board should defer to a settlement agreement in the arbitration process. In Titanium Metals, unlike in Plumbers and Pipefitters, the Board had refused to defer to the settlement because it was not convinced that the agreement was "fair and regular." See id. at 448. Judge Edwards concluded that the Board abused its discretion in declining to defer to the settlement, which provided that the grievant "was 
Judge Edwards's waiver theory thus comfortably fits deference to a settlement of a grievance in the arbitration process, as a settlement between a bargaining representative and an employer can always be treated as a modification of the collective agreement.

His waiver theory also fits deference to a completed arbitration award, however, as such an award also can be viewed as a modification of the agreement by construction or by the filling of gaps in the agreement's meaning through the parties' chosen process. As stated by Judge Edwards, the "arbitrator's interpretation of the contract is, in essence, part of the contract." 37

Consider, for instance, the arbitration decision to which the Board gave deference in Olin Corp. ${ }^{38}$ The grievant in Olin, like the discharged union president in Metropolitan Edison, was terminated, at least in part, for failing to prevent a work action in breach of a no-strike clause in a collective agreement. ${ }^{39}$ The arbitrator concluded that the grievant's "participation in the strike action was inconsistent with his manifest contractual obligation to attempt to stem the tide of unprotected activity." 40 This construction of the collective agreement defines the obligations of union officer-employees and the discretion of the employer to discipline for breach of those obligations. The arbitration award thereby clearly and unmistakably completes an agreement to waive $\S 7$ rights of union officers that the Court in Metropolitan Edison held to be subject to the control of a bargaining representative, ${ }^{41}$ a bargaining representative like the one in Olin that agreed to delegate its control to an arbitration process. The arbitration award in Olin, in other words, like the settlement agreement in Plumbers and Pipefitters, defines relevant $\S 7$ rights.

Judge Edwards's waiver theory also provides a rationale for the Board's policy of deferring decisions on some unfair labor practice charges to the completion of arbitration processes under certain conditions. These conditions, as first pronounced by the Board in Collyer Insulated Wire ${ }^{42}$ and

not discharged for engaging in protected concerted activities under the NLRA," id. at 444, but he did not further elaborate his waiver theory. Judge Edwards did posit waiver as a basis for Board deferral in the case, however. He asserted that the $\S 7$ right claimed by the employee grievant, the right to distribute a newsletter critical of the employer's labor policies to fellow employees, was waivable, and then concluded that the Board had no basis for questioning the fairness and regularity of the arbitration process and a grievance settlement. Id. at 447-50. For further discussion of Titanium Metals, see infra text accompanying notes 73-84.

37 See Edwards, supra note 19, at 31.

268 N.L.R.B. 573 (1984).

Id. at 573 .

$I d$.

41 In my view, wrongly. See supra note 25.

42192 N.L.R.B. 837 (1971). 
as confirmed in United Technologies Corp., ${ }^{43}$ include "a long and productive collective bargaining relationship," "no claim of employer animosity to the employees' exercise of protected rights," a broad arbitration clause encompassing the dispute, the employer's asserted "willingness" to arbitrate, and the dispute being "eminently well suited to resolution by arbitration." 44 The O-M Memorandum did not reference this policy; it mentioned only the Board's policy of deference to completed arbitration awards. If Judge Edwards's waiver theory is accepted for post-arbitration deference, however, it also should be accepted as a basis for the Board's deferring the consideration of unfair labor practice charges based on waivable statutory rights when conditions similar to those set forth in Collyer and United Technologies are met. If a collective agreement could effectively waive or otherwise define a statutory right upon which a charge is based and if the parties have designated an arbitration process to determine the meaning of that agreement, then the Board should attempt to utilize the process when the employer is willing to cooperate in doing so.

In his article on Board deferral, Judge Edwards indicated that the Board should avoid unnecessary interpretations of collective agreements, at least when considering $\S 8(\mathrm{a})(5)$ charges, by treating an arbitration clause as itself "a waiver of the duty to bargain," or, in other words, as a statement that the arbitrator should define the extent to which the parties have a duty to bargain during the term of an agreement. ${ }^{45}$ Judge Edwards's argument is particularly applicable to the issue in the cases his article discussed to illustrate the Board's difficulty interpreting collective agreements, the Board's two inconsistent decisions in the 1980s Milwaukee Spring controversy. ${ }^{46}$ The issue in these cases was whether the employer was constrained by clauses in a collective agreement from transferring assembly operations, even after bargaining to impasse, from the facility covered by the agreement to another facility that was not organized. If the clauses in the collective agreement implicitly created a duty not to transfer the work, the employer's doing so would have violated its duty, enforced through $\S$ $8(\mathrm{a})(5)$ and defined in $\S 8(\mathrm{~d})$ of the Act, ${ }^{47}$ not to modify "terms and condi-

43268 N.L.R.B. 557 (1984). The Board in United Technologies, rejecting Chairman Murphy's opinion in General American Transportation, see supra text accompanying note 9, also clarified that it would defer to the arbitration process under the Collyer conditions in complaints under $\S \S 8(\mathrm{a})(1)$, 8(a)(3), 8(b)(1)(A), and 8(b)(2), as well as $\S \S 8(a)(5)$ and 8(b)(3). See id. at 560.

44 Id. at 558 (citing Collyer, 192 N.L.R.B. at 837).

45 See Edwards, supra note 19, at 34-35.

46 Milwaukee Spring Div. of Ill. Coil Spring Co. (Milwaukee Spring II), 268 N.L.R.B. 601 (1984); Milwaukee Spring Div. of Ill. Coil Spring Co. (Milwaukee Spring I), 265 N.L.R.B. 206 (1982).

4729 U.S.C. $§ 158(d)(2006)$. 
tions contained in" the agreement during its term. ${ }^{48}$ If the clauses were not relevant to the work transfer, the employer did not commit an unfair labor practice. $^{49}$ Thus, the union's claim that the employer had committed a $\S$ $8(a)(5)$ violation was based on the employer being constrained by contract clauses, the meaning of which could have been settled through arbitration. An arbitration process would define the extent of the statutory right. Had the union had "access to arbitration," which Judge Edwards assumed it did not, ${ }^{50}$ the waiver theory thus would have required the Board to defer its consideration of the statutory charge until the arbitrator had interpreted the agreement.

The waiver theory also indicates the Board generally should defer until the completion of an available arbitration process deciding the more usual $\S$ 8(a)(5) charge of a refusal to bargain during the term of the agreement. This charge, which Judge Edwards did not distinguish in his analysis, alleges that the employer failed to bargain to impasse before effecting a change in a term or condition of employment subject to mandatory bargaining. The contract becomes relevant not, as in Milwaukee Spring, as the basis for the union's charge, but rather as the basis for the employer's defense, which claims that the union has accepted management's right to have discretion over the term or condition during the term of the agreement. This acceptance would constitute a waiver of the $\S 7$ right, protected through $\S 8($ a)(5), "to engage . . . in collective bargaining,", a right clearly under the control of the exclusive bargaining representative.

Consider, for instance, the issue in Collyer Insulated Wire. ${ }^{52}$ The complaint in that case alleged that the employer violated $\S 8(\mathrm{a})(5)$ by making unilateral changes in certain wages and work assignments within the bargaining unit. 53 The employer contended "that its authority to make those changes was sanctioned by the collective-bargaining contract between the parties and their course of dealing under that contract." ${ }^{54}$ The employer relied on a provision in the contract that bound it not to change "the general scale of pay," but also seemed to authorize "adjustments in individual rates from time to time to remove inequalities or for other proper reasons."

\footnotetext{
48 Id. This was the interpretation given the agreement by the Board in Milwaukee Spring I. See 265 N.L.R.B. at 208.

49 This was the interpretation given the agreement by the Board in Milwaukee Spring II. See 268 N.L.R.B. at 602.

50 See Edwards, supra note 19, at 34.

29 U.S.C. $\S 157$ (2006).

192 N.L.R.B. 837 (1971).

Id. at 837 .

Id.

5 Id. at 838-39.
} 
employer also relied on negotiating history ${ }^{56}$ and on a provision allowing the union to challenge through a grievance and arbitration process the employer's pay rates for new or changed jobs and on the contract's generally broad "grievance and arbitration machinery." ${ }^{57}$ Given the comprehensive terms of the contract and the negotiating history described in the Board's decision, it was highly likely that any decision rendered through that machinery would determine whether the union in fact had "sanctioned" the employer's changes in wages and working conditions, in other words whether it had waived the right to bargain over these changes during the term of the agreement. A decision that found the agreement not to restrict the employer's discretion to make the challenged changes, would find the agreement to authorize the discretion. A decision finding no contractual violation thus would mean there was no statutory violation.

The waiver theory also supports Board deferring, until the completion of arbitration processes meeting the Collyer/United Technologies conditions, decisions on complaints based on waivable $\S 7$ rights other than those to engage in collective bargaining. As is true for $\S 8(\mathrm{a})(5)$ complaints, this is most clear for the limited number of other complaints that directly depend on a provision in a collective agreement. Consider, for instance, a $\S$ $8(\mathrm{a})(1)$ complaint, like that supported by the Court's decision in NLRB v. City Disposal Systems, Inc., ${ }^{58}$ that an employer has disciplined an individual employee for invoking a clause in a collective agreement. The Court in City Disposal approved as within the Board's discretion its treatment of an individual's assertion of a right based in a collective agreement as "concerted" within the meaning of $\S 7 .^{59}$ Citing Collyer as well as Spielberg, however, the Court also noted that the Board might defer to a "grievance process" the resolution of whether such concerted activity was also protected from employer retaliation. ${ }^{60}$ Such deferral of a right's protection to a process sanctioned by the union in the collective agreement to define the agreement's meaning is consistent with the right's dependence upon the union's concerted, collective action in the creation of the agreement. Thus, just as the union's negotiation of a contractual right in City Disposal not to drive unsafe vehicles ${ }^{61}$ makes the invocation of that right by an individual employee concerted and therefore protected, the union accepts quali-

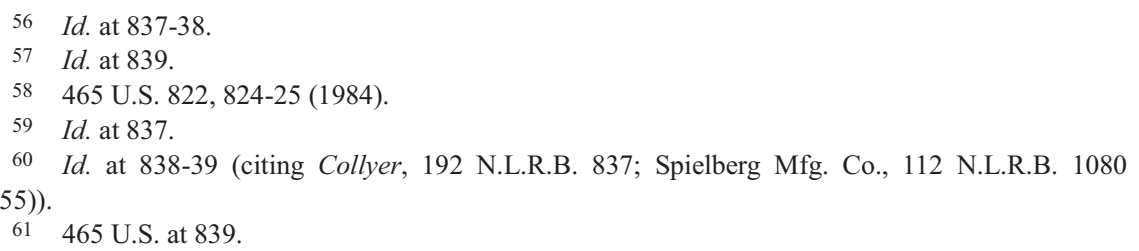


fication of that protection by providing for the right to be defined through a grievance and arbitration process.

Judge Edwards's waiver theory, moreover, supports the deferral to the completion of an arbitration process of waivable rights of individual employees that would be secured by $\S 7$ in the absence of any collective agreement. Consider, for instance, a case in which not just one, but two employees, together refuse to drive vehicles that they consider unsafe. The concerted nature of their refusal is not dependent upon their invocation of any collective agreement because they are acting together as well as for their mutual protection. The employees' statutory rights to engage in concerted action to obtain better, including safer, conditions of employment from their employer, however, are within the control of their exclusive bargaining representative. The exclusive representative's negotiation of a collective agreement both defining the employer's discretion to control and discipline employees and also establishing an arbitration process to define the extent of that discretion thus supports the Board at least waiting for the completion of that process before deciding whether any rights have been abridged. The waiver theory is as applicable to the Board's pre-arbitration deferral of waivable statutory rights as it is to the Board's deference to completed arbitration decisions and settlements.

\section{B. A Recommended Response for the Board}

As recognized by the O-M Memorandum at least for Board deference to completed arbitration decisions, the Board should reconsider its deferral doctrine in the light of Judge Edwards's waiver theory. Since the grievance arbitration process is a continuation of collective bargaining, grievance settlements and arbitration decisions should be considered to be part of an exclusive bargaining agent's agreement with the employer. When the Board reads such settlements or decisions to clearly and unmistakably waive or otherwise qualify statutory rights within the control of the exclusive representative, it usually should accept such a waiver or qualification. This acceptance should not be dependent upon the arbitration decision or the settlement agreement being based on the same analysis of the meaning of the extant collective agreement that the Board would apply under its own "clear and unmistakable" waiver analysis. An arbitration decision or settlement agreement, like any other negotiated modification of an agreement, cannot be palpably wrong or clearly repugnant to the Act merely because it is not clearly suggested by or even because it departs sharply from a prior agreement. Indeed, the Board need not even demand an express or implicit acknowledgement in an arbitration decision or settlement agreement that there has been a waiver of a statutory right, as long as the decision or agreement clearly authorizes the employer's restraint of a 
waivable employee right, rather than merely finds no contractual limitation on such restraint.

The Board also should invoke the waiver theory to support its prearbitration deferral policy under the Collyer/United Technologies conditions. When the parties have access to a fair and functioning grievance arbitration process that they have established in part to define their rights and obligations, the Board should demand that this process be used when unfair labor practice complaints are based on waivable statutory rights. Doing so encourages arbitration as a peaceful and efficient means for resolving disputes in accord with the national labor policy, as the Board has stressed. $^{62}$ Doing so, as the waiver theory highlights, also requires the parties to accept their full agreement, which includes use of the arbitration process to define rights and obligations.

The Board, nonetheless, should not fully embrace the waiver theory for Board deferral as developed in Judge Edwards's opinions for panels of the District of Columbia Circuit Court of Appeals. These decisions reveal several flaws in the theory as articulated by Judge Edwards. First, Judge Edwards at least implicitly compromises the important requirement, confirmed by the Court in Metropolitan Edison, that a union waiver of a statutory right must be "clear and unmistakable." He does so by articulating a standard for Board deference requiring consideration only of whether the statutory right on which a claim was based was waivable and whether the grievance arbitration process was fair, ${ }^{63}$ but not whether the arbitration decision or settlement agreement actually found union authorization of a waiver or qualification of the right.

Judge Edwards overtly rejects the "clear and unmistakable" standard in cases reviewing findings of employer unilateral changes in mandatory terms by asserting that where a topic is "covered by the collective bargaining agreement, the union has exercised its bargaining right and the question of waiver is irrelevant." ${ }^{64}$ Judge Edwards's somewhat ironic rejection of "the question of waiver" in this context reflects his view that where a union negotiates in a collective agreement a limitation on employer authority on some topic, it necessarily forfeits any right to bargain further during the term of the agreement over the employer's exercise of discretion on that topic. ${ }^{65}$ On topics covered by a collective agreement, there is thus in effect

62 Olin Corp., 268 N.L.R.B. 573, 574 (1984); Collyer, 192 N.L.R.B. at 843.

63 See Edwards, supra note 19, at 28-30.

64 NLRB v. U.S. Postal Serv., 8 F.3d 832, 836 (D.C. Cir. 1993) (Edwards, J.) (quoting Dep't of Navy v. Fed. Labor Relations Auth., 962 F.2d 48, 57 (D.C. Cir. 1992) (Edwards, J.) (emphasis in original)).

65 Judge Edwards asserts this follows from the proposition that "[u]nless the parties agree otherwise, there is no continuous duty to bargain during the term of the agreement with respect to a matter 
no difference for Judge Edwards between the question of whether an agreement authorizes the employer's action and the question whether the agreement prohibits the action. That which the agreement does not prohibit, it must authorize.

In most cases, Judge Edwards's elision of the distinction between the questions of contractual authorization and contractual prohibition is not problematic. Collective bargaining agreements that prohibit certain kinds of subcontracting or work assignments or incentive pay usually would be read by arbitrators to authorize the employer to implement unilaterally other kinds of subcontracting or work assignments or incentive pay. In most cases, but certainly not in all cases. In some cases, arbitrators, perhaps based on evidence of negotiating history, might find the intent to leave for future bargaining certain additional employer actions related to but not prohibited by the negotiated agreement. In those cases the arbitrator could decide the agreement does not prohibit the employer unilaterally taking such actions without deciding the agreement authorizes the actions. The arbitrator, in other words, could decide the contractual issue in favor of the employer without finding the union to have waived the statutory right of represented employees, as secured by $\S 8(\mathrm{a})(5)$, to bargain collectively.

Before dismissing $\S 8(\mathrm{a})(5)$ unilateral change complaints based on the resolution of contractual grievances, the Board thus should be assured that those resolutions actually decided that the employer's discretion to act unilaterally was authorized by the union, rather than only that the union failed to secure an agreement to prohibit the action. While the collective agreement itself need not clearly and unmistakably waive the $\S 7$ right to bargain collectively, an arbitration decision, or grievance settlement agreement, at least must do so. Furthermore, the Board should continue to consider as a condition of deferring consideration of a $\S 8(\mathrm{a})(5)$ unilateral change charge

covered by the contract." 8 F.3d at 836 . Judge Edwards's support for this proposition, however, does not support freeing an employer to take any unilateral action on topics covered by an agreement, unless the agreement actually prohibits the action. Judge Edwards cites his own opinion, International Union, United Auto Workers v. NLRB, 765 F.2d 175 (D.C. Cir. 1985), upholding the Board's second Milwaukee Spring decision, Milwaukee Spring Div. of Ill. Coil Spring Co. (Milwaukee Spring II), 268 N.L.R.B. 601 (1984), and the Court of Appeals decision upholding the Board's seminal decision on midterm bargaining obligations, NLRB v. Jacobs Mfg. Co., 196 F.2d 680 (2d Cir. 1952), affirming Jacobs Manufacturing Co., 94 N.L.R.B. 1214 (1951). U.S. Postal Serv., 8 F.3d at 836. Jacobs Manufacturing confirms that an employer has no statutory duty to bargain over a union's request to modify terms and conditions "contained in" a collective agreement during the agreement's term, see 196 F.2d at 683-84; it does not give any warrant to an employer modifying without bargaining terms related to a topic covered in the agreement. The United Auto Workers decision upheld what it considered to be a Board determination that a particular collective bargaining agreement authorized a relocation of work, see 765 F.2d at 177; it did not hold that an employer has no continuing duty to bargain before making any changes not prohibited by any extant agreement that covers a topic related to the changes. 
to the completion of the grievance arbitration process, whether the charge is "eminently well suited to resolution by arbitration." ${ }^{66}$ In some cases, this should include consideration of whether settlement of the issue of prohibition is likely to settle the statutory issue of authorization as well. ${ }^{67}$

Similar considerations are relevant to Board deferral of unfair labor practice complaints against employer discipline allegedly imposed in response to an employee's engagement in $\S 7$ protected activity under the control of an exclusive representative. In most cases, an arbitrator's decision that an employer had just cause to take disciplinary action determines not only that the agreement does not prohibit the discipline, but also that the discipline is authorized by the agreement. In some cases, however, an arbitration award might conclude only that the agreement cannot be the source of any restraint on the employer's discretion, without even considering the possibility of other sources, such as the NLRA. An arbitration award, for instance, might find in the collective agreement no restraint on an employer's discretion to discharge an employee for refusing to submit to a disciplinary interview in the absence of a union officer, without taking any position on whether such a restraint might be found in the Board doctrine 44.

66 Collyer Insulated Wire, 192 N.L.R.B. 837, 842 (1971). See supra text accompanying notes 42-

67 The Board also should continue to adhere to the "clear and unmistakable" waiver standard in evaluating employer contract-based defenses in $\S 8(a)(5)$ unilateral change cases in which deferral to an arbitration process is not sought or is otherwise inappropriate. See, e.g., NLRB v. Provena Hosp., 350 N.L.R.B. 808, 808 (2007). Although the Board has discretion to interpret broad management rights clauses to clearly authorize actions not prohibited by the contract, $c f$. Chicago Tribune v. NLRB, 974 F.2d 933, 934 (7th Cir. 1992) (questioning the application of a clear waiver standard to a broad management rights clause and interpreting the clause de novo), the Board should continue to resist full acquiescence to Judge Edwards's alternative contract-coverage standard. Full acquiescence to this standard would force the Board to dismiss any complaint charging a unilateral change on a matter covered by a collective agreement during the agreement's term. See NLRB v. U.S. Postal Serv., 8 F.3d 832, 836-37 (D.C. Cir. 1993); see also, e.g., Enloe Med. Ctr. v. NLRB, 433 F.3d 834, 837-38 (D.C. Cir. 2005) (Silberman, J., relying on U.S. Postal Serv.); cf. Bath Marine Draftsmen's Ass'n v. NLRB, 475 F.3d 14, 26 (1 st Cir. 2007) (suggesting the Board can apply a contract-coverage standard if it chooses). Judge Edwards's standard denies a union the discretion to bargain for contractual restraints on employer prerogatives on a topic without sacrificing its statutory right to prevent the employer from taking other unilateral action on the topic during the term of the agreement. The Board appropriately can demand that an employer who wishes to obtain authorization to change terms and conditions of employment during the term of an agreement do so either through a management rights clause that expressly provides such authority or by bargaining for and invoking an arbitration process that allows it to attempt to secure confirmation of the authority from an arbitrator to whom the Board might appropriately defer. Contrary to Judge Edwards's assertion in his article on deferral, without such an arbitral confirmation, protecting the union's status as collective representative provides good reason "why an arbitration clause [alone] should not be viewed as a waiver of the right to charge an unfair labor practice with respect to unilateral changes made during a contract term." See Edwards, supra note 19, at 33-34. 
affirmed in NLRB v. J. Weingarten, Inc. ${ }^{68}$ Even settlement agreements, though presumably covering all sources of possible restraints on employer authority subject to the union's control, might expressly cover only those restraints imposed by the contract. Thus, the Board should not defer its decision on any charge of a deprivation of a waivable statutory right to a resolution of an arbitration process under a collective agreement without considering whether that resolution actually clearly and unmistakably found union authorization of the challenged action. ${ }^{69}$

In addition to adding a condition requiring the arbitration resolution to have considered the statutory claim, the Board also should strengthen the minimal conditions listed in the decisions cited in the O-M Memorandum by Judge Edwards for accepting deference to the resolution of arbitration grievances under collective agreements. Those conditions are that grievance procedures be "fair and regular" and that "the union has not breached its duty of fair representation.," Judge Edwards imports the "fair and regular" condition from the Board's current conditions for deferring to arbitration decisions and settlement agreements. He presumably adds the "duty of fair representation" condition because the duty of fair representation is an obligation that is imposed on unions as an implied corollary to their status as exclusive representatives with authority to balance the interests and certain rights of represented employees. ${ }^{71}$ Judge Edwards recognizes that unions' authority as exclusive representatives to waive or otherwise qualify statutory rights through the arbitration process must be conditioned on their doing so in accord with the minimal standards of fairness imposed by the union's duty of fair representation - that its balancing of employee interests not be "discriminatory, arbitrary or in bad faith.",

68420 U.S. 251 (1975). In my view, the $\S 7$ right "to refuse to submit without union representation to an interview which [the employee] reasonably fears may result in his discipline," 420 U.S. at 256 , is an economic right to take concerted action to achieve a better condition of employment and is thus subject to union control. See Harper, supra note 11, at 357-60.

69 In his opinion in Plumbers and Pipefitters, Judge Edwards dismisses as factually inaccurate an argument that the union "specifically disclaimed any intention of resolving the statutory issue." Plumbers \& Pipefitters Local Union No. 520 v. NLRB, 955 F.2d 744, 755 (D.C. Cir. 1992). The opinion does not state whether deference would have been inappropriate if the union had in fact so "disclaimed," however.

$70 \quad$ Id. at 756.

71 See Syres v. Oil Workers Local 23, 350 U.S. 892 (1955) (confirming the duty exists for exclusive bargaining agents under the NLRA); Steele v. Louisville \& Nashville Ry. Co., 323 U.S. 192, 202 (1944) (finding such a duty for exclusive bargaining agents under the Railway Labor Act).

72 The formal standard for breach of the duty of fair representation, whether in contract administration or negotiation, is "arbitrary, discriminatory, or in bad faith." See, e.g., Air Line Pilots Ass'n Int'l v. O’Neill, 499 U.S. 65, 67 (1991); Vaca v. Sipes, 386 U.S. 171, 190 (1967). For an explanation of this standard as requiring the same kind of principled decision making required of governments by the 
Judge Edwards, however, does not acknowledge that the Board's "fair and regular" condition can provide additional, reinforcing protection of this fairness beyond that provided by the necessarily vague and liberal general duty of fair representation standard cited above. Such reinforcement, while not appropriate as a modification of the duty of fair representation generally, seems a particularly appropriate condition for the indirect waiver of statutory rights through a contractual arbitration process.

Consider the more recent decision of the District of Columbia Circuit Court of Appeals cited in the O-M Memorandum, Titanium Metal Corp. v. $N L R B{ }^{73}$ In this case, in an opinion by Judge Edwards, the court refused to accept the Board's decision not to defer to a grievance settlement its decision on an unfair labor practice complaint that an employer had discharged an employee for publishing and distributing to other employees a newsletter that included articles critical of supervisors and the employer's labormanagement policies. ${ }^{74}$ The grievance settlement explicitly concluded as a finding of fact that the grievant "was not discharged for engaging in protected concerted activities under the NLRA," but rather for other conduct that would not be protected by $\S 7 .{ }^{75}$ The union's agreement to this finding of fact, whether or not correct, was a clear and unmistakable waiver of any $\S 7$ right that the grievant had to publish and distribute the newsletter. Assuming any such right was under the control of the union, ${ }^{76}$ Judge Edwards correctly concluded that the Board was bound to give effect to the settlement agreement as a resolution of the statutory complaint - unless the settlement seemed to be an unfair union sacrifice of the interests of the grievant. For Judge Edwards, the latter possibility could be easily dismissed because there was "no claim that the Union breached its duty of fair representation." ${ }^{77}$

The Board in Titanium, however, declined to defer because of its finding that the process resulting in the settlement agreement was not "fair and regular." ${ }^{78}$ This finding was based on the settlement agreement providing different reasons for the discharge than those given the grievant at the time of the discharge, and on the union's failure to disclose the agreement to the grievant when notifying him it would not take his grievance to arbi-

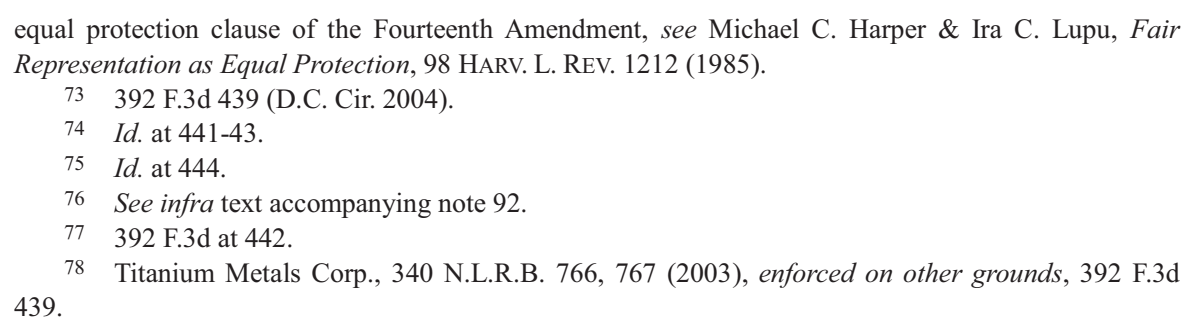


tration. ${ }^{79}$ The Board concluded that these factors suggested "an attempt to disguise the real reason for the discharge," the grievant's protected distribution of the newsletter to other employees. ${ }^{80}$ The Board's decision did not speculate on why the union would have wanted to participate in such a masquerade, but one can imagine the grievant's newsletter and criticisms making life more difficult for union as well as company officials. Not surprisingly, the Board did not conclude that the union had breached its duty of fair representation in accepting the settlement; it had insufficient information to make such a charge against the union and the Board has never made such a conclusion important to a finding of sufficient irregularity to warrant a refusal to defer to an arbitration resolution. Nevertheless, the Board made evident its uncertainty about the union's good faith in settling the grievance, and thereby perhaps in waiving the grievant's statutory protections.

Judge Edwards dismissed the Board's concerns about the different reasons for discharge given in the settlement and the failure to provide the settlement to the grievant by stressing that the employer and union had breached no formal legal obligation. ${ }^{81}$ He concluded that the Board could not refuse to defer on the "whim" of a suspicion. ${ }^{82}$ For him, apparently, the "fair and regular" standard provides a reason not to defer only if there was a clear departure from the processes set forth in the agreement or otherwise previously used by the parties. The standard is not a means to ensure the union's good faith in balancing the interests and rights of represented parties.

In my view, the Board should use the "fair and regular" standard in part $^{83}$ for this latter purpose, perhaps with a fuller explanation of the

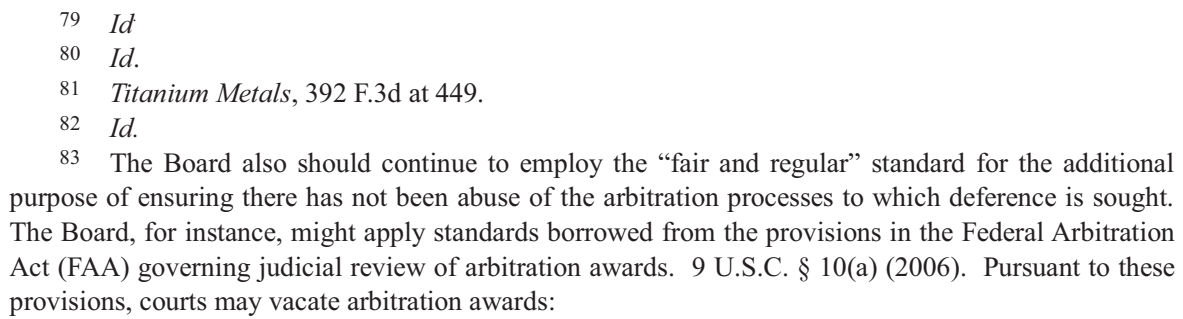

33 The Board also should continue to employ the "fair and regular" standard for the additional purpose of ensuring there has not been abuse of the arbitration processes to which deference is sought. The Board, for instance, might apply standards borrowed from the provisions in the Federal Arbitration Act (FAA) governing judicial review of arbitration awards. 9 U.S.C. $\$ 10$ (a) (2006). Pursuant to these provisions, courts may vacate arbitration awards:

(1) where the award was procured by corruption, fraud, or undue means; (2) where there was evidence of partiality or corruption in the arbitrators, or either of them; (3) where arbitrators were guilty of misconduct in refusing to postpone the hearing, upon sufficient cause shown, or in refusing to hear evidence pertinent and material to the controversy, or of any other misbehavior by which the rights of any party have been prejudiced; or (4) where the arbitrators exceeded their powers, or so imperfectly executed them that a mutual, final, and definite award upon the subject matter submitted was not made.

Id. 
particular importance of ensuring good faith, non-arbitrary, and nondiscriminatory union decision-making where statutory rights are at stake. The waiver theory is based on the authority of exclusive bargaining representatives to waive certain substantive statutory rights that the Board also is vested with authority to protect. The Board surely has discretion to exercise its own authority to protect these rights when it has reason to suspect an exclusive bargaining representative is exercising its waiver authority in bad faith. The Board in declining to defer to a union waiver should not have to have as definitive evidence of such bad faith as it would to find the union vulnerable to monetary damages ${ }^{84}$ because it has committed an unfair labor practice in breaching its duty of fair representation.

Third, the Board should strengthen the distinction made in Judge Edwards's waiver theory between Board deferral of complaints alleging the deprivation of waivable $\S 7$ rights and those alleging the deprivation of nonwaivable rights. That strengthening could follow the elaboration I gave almost thirty years ago to Chairman Murphy's suggestion that the Board, based on the Court's decision in NLRB v. Magnavox Co., ${ }^{85}$ must limit the kinds of cases it defers to an uncompleted arbitration process. ${ }^{86}$ Judge Edwards recognizes that his waiver theory does not apply to those $\S 7$ rights not under the control of exclusive bargaining representatives, but neither his opinions nor his article on deferral pays sufficient attention to the broad scope of the $\S 7$ rights the Magnavox decision indicates cannot be compromised by unions.

In Magnavox, the Court affirmed a Board finding that an employer's prohibition of the distribution of literature on company property could not be applied against the distribution during non-work time and in non-work areas of literature critical or supportive of the union representative, despite the apparent authorization of the rule in the collective agreement. ${ }^{87}$ The Court distinguished waivable "rights in the economic area," such as the right to strike or take other economic action to extract better terms of employment from an employer, from non-waivable "rights of the employees to exercise their choice of a bargaining representative." 88 Over the dissent of

84 See, e.g., Bowen v. U.S. Postal Serv., 459 U.S. 212, 222 (1983) (holding that where an employee successfully sues employer for breach of agreement and union for breach of duty of fair representation, an allocation of damages between employer and unions is required); Int'l Bd. of Elec. Workers v. Foust, 442 U.S. 42, 50-52 (1979) (considering the threat of damage awards debilitating union treasuries in holding not to allow punitive damages for breach of duty of fair representation).

85415 U.S. 322 (1974).

86 See Harper, supra note 8; see also Harper, supra note 11.

87415 U.S. at 326.

88 Id. at 325. 
three Justices, ${ }^{89}$ the Court in Magnavox insulated from union waiver the protection of communications between employees in support of the continuation of the bargaining representative as well as communications against the representative. ${ }^{90}$ The former communications, like the latter, are about the employees' choice of a representative; they are not, like a strike or collective bargaining, a direct effort to extract terms from an employer.

This distinction indicates a broader range of non-waivable $\S 7$ rights than Judge Edwards seems to assume. In his article on deferral, Judge Edwards asserts that Magnavox holds "a union may not waive the employees' rights to choose a new bargaining representative, because on that particular issue the interests of the union and the workers diverge." ${ }^{91}$ Non-waivable $\S 7$ rights, for Judge Edwards, thus are those "in which the union and employee interests are potentially adverse." ${ }^{92}$ This position seems to more closely reflect that of the dissenters than that of the majority in Magnavox, and it may obscure the potential for the sacrifice of rights the majority's position would protect from waiver.

For instance, the newsletters that the grievant in Titanium Metals alleged he was discharged for distributing probably included, in addition to criticisms of the employer's labor relations, at least implicit advocacy of steps the union should take in response. Such advocacy would have constituted an attempt to redefine the nature of the employees' collective representative rather than a direct economic action to extract better conditions from the employer. Thus, the grievant's $\S 7$ right to distribute the newsletters would not have been a right fully "in the economic area" and waivable by the union. ${ }^{93}$ The Board therefore had another good reason not to defer to the union's settlement of the grievance.

Because Judge Edwards's theory of substantive waiver through arbitration is not applicable to non-waivable $\S 7$ rights, the Board should not be required to defer to the arbitration process any complaint of an unfair labor practice that might threaten the exercise of the broad range of non-waivable $\S 7$ rights suggested by the Magnavox decision. The General Counsel

89 Id. at 327 (Stewart, Powell, and Rehnquist, JJ., concurring in part and dissenting in part).

90 Id. at 325-26 (majority opinion).

91 Edwards, supra note 19, at 30.

92 Id.

93 Indeed, a strong case can be made that the Board should posit a bright line rule insulating from union waiver the statutory protection of any communications between union-represented employees concerning terms and conditions of employment. See Harper, supra note 11, at 354 n.85. Most such communications implicitly advocate some response from the employees' collective representative, and thus are about determining the nature of that representative. For instance, the newsletters in Titanium Metals, unlike flyers distributed to customers, probably were not in themselves part of some extra-union effort to extract better terms and conditions of employment from the employer, but rather part of an attempt to convince fellow employees to pressure the union to take action. 
should consider whether non-waivable rights might have been threatened in each case in which post-arbitration deference or pre-arbitration deferral is sought. And, as explained in the next section, in the exercise of its administrative discretion, the Board should weigh heavily the nature of any such threat when considering the potential utility of arbitration.

\section{THE COMMITMENT TO ARBITRATE AS A WAIVER OF PROCEDURAL RIGHTS}

The Board's attention to the distinction between waivable and nonwaivable $\S 7$ rights is particularly important in light of the Court's decision in 14 Penn Plaza, LLC v. Pyett ${ }^{94}$ to approve the enforcement of agreements between employers and unions to submit to arbitration claims of represented employees based on substantively non-waivable statutory rights. The timing of the O-M Memorandum a few months after the decision in Penn Plaza indeed suggests that this decision, more than Judge Edwards's old Court of Appeals opinions, is the primary impetus for any reconsideration the General Counsel may give to the Board's deferral doctrine.

In Penn Plaza, the Court held enforceable a provision in a collective bargaining agreement that "clearly and unmistakably" assigned to arbitration a claim under the Age Discrimination in Employment Act (ADEA). ${ }^{95}$ The Court stressed the authority granted by the NLRA to exclusive bargaining agents to negotiate for the arbitration of employment claims of represented employees, and it concluded this authority reaches any claim under a statute, like the ADEA, that does not preclude arbitration as a forum for the adjudication of claims. ${ }^{96}$ The ADEA's allowance of the assignment of claims to the arbitration forum had already been confirmed by the Court in Gilmer v. Johnson/Lane Corp., ${ }^{97}$ in which the Court upheld compelling an employee to arbitrate an ADEA claim based on his having acceded to his employer's demand that the employee assign all of his employment claims to arbitration. ${ }^{98}$ Given Gilmer, the Penn Plaza holding seems easily deducible; if an employer unilaterally can require its employees to accept the

\footnotetext{
94129 S. Ct. 1456 (2009).

95129 S. Ct. at 1466; see also 29 U.S.C. $\$ 621$ (2006).

6129 S. Ct. at 1466.

500 U.S. 20, 26-27 (1991).

98 Interstate/Johnson Lane required Gilmer as a condition of his employment to be registered as a securities representative with the New York Stock Exchange. Id. at 23. This registration in turn required him to agree to the arbitration of any dispute arising between him and his employer. Id. In Circuit City Stores, Inc. v. Adams, 532 U.S. 105 (2001), the Court confirmed that Gilmer applies outside the context of third-party regulation to all employment contracts other than those exempted from coverage of the Federal Arbitration Act because the employees, like seamen or railroad workers, are directly engaged in interstate or foreign commerce. See also 9 U.S.C. $§ 1$ (2006).
} 
employer's arbitration system as a condition of employment, it is difficult to understand why an employer and a union cannot bilaterally require an employee represented by the union to accept a negotiated arbitration system as a condition of employment within the bargaining unit. ${ }^{99}$ A unionnegotiated system, moreover, usually can be expected to be at least as protective of an employee's substantive rights as can a unilaterally imposed arbitration system.

The Court in Penn Plaza, however, does not authorize union waiver of the ADEA substantive right to be secure from age discrimination in employment, any more than the Court in Gilmer allowed individual waiver of this right. The Penn Plaza Court notes that the ADEA includes a provision that prohibits the prospective waiver of "rights or claims that may arise after the date the waiver is executed," sion covers waiver by an individual, it must apply only to substantive rights and not to the procedural right of action at issue. ${ }^{102}$ Moreover, the opinion's penultimate paragraph reaffirms that a "substantive waiver of federally pro-

99 This does not assume that unions should readily negotiate the assignment of all individual employees' statutory claims to arbitration. Unions may resist doing so because of the burdens of such an assignment on their limited treasuries and because of concerns about duty of fair representation claims brought against them by disappointed employees who did not obtain relief through arbitration. The Penn Plaza Court indeed stressed the union's duty of fair representation as a corrective against any union conflict of interest in the arbitration process. $129 \mathrm{~S}$. Ct. at 1473.

Nonetheless, unions presumably should prefer that they, rather than individual employees, have control over the potential assignment of statutory claims to arbitration. Were such assignments not a mandatory topic of bargaining, employers could devalue unions as representatives by imposing arbitration on represented employees without any bargaining. See Air Line Pilots Ass'n, Int'1 v. Nw. Airlines, Inc., 199 F.3d 477, 485 (D.C. Cir. 1999) (employers can impose compulsory arbitration of statutory rights on union-represented employees under the assumption that such arbitration is not a mandatory topic for bargaining). Under the Penn Plaza holding, in contrast, unions can decide whether to accept the arbitration of particular statutory rights in order to secure other more favorable terms and conditions of employment for the bargaining units they represent. Although unions are obligated to bargain over the scope of arbitration jurisdiction, employers cannot unilaterally impose arbitration over topics the union does not accept, even after bargaining to impasse. $C f$. Litton Fin. Printing Div. v. NLRB, 501 U.S. 190, 208-09 (1991) (upholding Board doctrine that commitment to arbitration does not extend beyond expiration of agreement because arbitration is consensual) (citing United Steelworkers of Am. v. Warrior \& Gulf Navigation Co., 363 U.S. 574, 582 (1960) (federal labor policy is that "arbitration is a matter of contract and a party cannot be required to submit to arbitration any dispute which he has not agreed so to submit")). Furthermore, unions should be able to protect themselves from exposure to duty of fair representation suits by allowing employees the right to press their own statutory claims through arbitration, an allowance that employers presumably would accept to ensure that employees not retain rights to invoke judicial jurisdiction. See infra text accompanying note 105.

100 This condition of at least equal procedural protection through a union-negotiated system, however, may not always be met. For instance, if only the union and employer, rather than individual employees, choose arbitrators, the arbitrators may be less likely to be sensitive to employee claims not pressed by the union. See infra note 107.

10129 U.S.C. $\S 626(f)(1)(C)(2006)$.

102129 S. Ct. at 1465. 
tected civil rights will not be upheld."103 The opinion suggests that if the union blocked arbitration of the ADEA claims, and thus denied the alternative forum of arbitration, the union would be sacrificing a substantive antidiscrimination right. The Court, however, did not find adequate evidence in the record "to resolve in the first instance" whether the bargaining agreement "allows the Union to prevent [employees] from "effectively vindicating' their 'federal statutory rights in the arbitral forum.",104

The Board must recognize the Penn Plaza Court's distinction between substantive and procedural waiver in any reformulation of its deferral policy. Judge Edwards's theory postulates that an agreement to arbitrate effectively waives additional Board protection of those substantive $\S 7$ rights subject to the union's control. Under this theory the Board should respect an arbitration decision or grievance settlement even if it modifies or fully sacrifices a waivable substantive right, like the right to strike; but if the decision or settlement compromises a non-waivable right in any way, the theory is inapplicable. Because the waiver accepted in Penn Plaza is only procedural, by contrast, it supports the assignment to an arbitration process of rights of action to secure non-waivable, as well as waivable, rights, but only to the extent that the process does not compromise the substantive rights. As suggested in Penn Plaza, substantive waiver would occur if employees were prevented from "effectively vindicating" their statutory rights in an "arbitral forum." Presumably, any final union settlement of an employee's statutory claim that is not accepted by that employee would prevent vindication of the claim in an arbitral forum and thus would constitute an ineffective substantive waiver. ${ }^{105}$ Furthermore, even if a union, after itself declining the claim, permitted the employee to proceed independently to an arbitration hearing, the claim could effectively be sacrificed. This might be the case, for instance, if the employee had no role in choosing the arbitrator ${ }^{106}$ or if the employees' costs of paying the arbitrator were prohibitive. ${ }^{107}$

103129 S. Ct. at 1474 (citing Mitsubishi Motors Corp. v. Soler Chrysler-Plymouth, Inc., 473 U.S. 614, 637 (1985)).

104 Id. (quoting Green Tree Fin. Corp.-Ala. v. Randolph, 531 U.S. 79, 90 (2000)).

105 Settlements like those in the two waiver decisions of Judge Edwards cited in the O-M Memorandum, Plumbers and Pipefitters, and Titanium Metals, see supra note 4, thus could not sacrifice an effective forum for the vindication of non-waivable substantive statutory rights like those protected by the ADEA or by the interpretation of $\S 7$ of the NLRA given by the Court in Magnavox, see supra note 11.

106 See, e.g., Hooters of Am. v. Phillips, 173 F.3d 933, 938-40 (4th Cir. 1999) (arbitration not enforceable because of employer's egregiously unfair arbitration rules, including selection procedures ensuring control of membership of arbitration panel).

107 See, e.g., Cole v. Burns Int'l Sec. Serv., 105 F.3d 1465, 1483-85 (D.C. Cir. 1997) (Edwards, J.) (requiring employee to pay arbitrators' fees could undermine substantive rights by creating barrier to 
Even more importantly, the Board also must recognize that Penn Plaza, like the Gilmer decision on which it relied, concerned the assignment to arbitration of a private right of action granted by the ADEA; the Penn Plaza decision did not grant unions authority to replace public administrative processes with a private arbitral process. To the contrary, the Penn Plaza Court cited its earlier decision in Equal Employment Opportunity Comm. v. Waffle House, Inc., ${ }^{108}$ which had held that an employee's agreement to arbitrate employment discrimination claims did not limit the EEOC's authority to seek victim-specific relief for that employee in a judicial action. The Waffle House Court reserved whether a settlement or arbitration judgment, through principles of res judicata or mootness, would affect the EEOC's claim or remedy, ${ }^{109}$ but it confirmed the public agency's "exclusive authority over the choice of forum and the prayer for relief once a charge has been filed." 110 This authority is necessary for the EEOC to "vindicate [the] public interest" it is charged with protecting. ${ }^{111}$

The NLRA, of course, provides no private right of action for the protection of $\S 7$ rights from unfair labor practices that could be waived in favor of arbitration. The only processes it provides are the Board's public administrative processes, ${ }^{112}$ which are to be utilized at the Board's discretion to protect the public interest in the free exercise of $\S 7$ rights, not just to secure some form of restitution for employees denied such freedom. ${ }^{113}$ Just as an individual employee's or his union's arbitration of statutory employment discrimination claims cannot waive the EEOC's statutory authority to address the same discrimination, neither can the employee's or union's arbitration of a claim of denial of a right secured by $\S 7$ of the NLRA waive the NLRB's authority to address the same denial. This is confirmed by $\S 10$ (a) of the NLRA, which provides that the Board's power to "prevent . . . unfair labor practice[s] . . . shall not be affected by any other means of adjustment or prevention that has been or may be established by agreement, law, or otherwise."

assertion of claims). But see Green Tree Fin. Corp., 531 U.S. 79, 92 (2000) (although large arbitration costs could preclude vindication of statutory right, party claiming such preclusion "bears the burden of showing the likelihood" of prohibitive costs).

108534 U.S. 279, 295 (2002).

109 Id. at $296-97$.

110 Id. at 298.

111 Id. at 296.

112 See 29 U.S.C $\S 160$ (2006) (covering Board processes for the adjudication and enforcement of unfair labor practice complaints).

113 See, e.g., Phelps Dodge Corp. v. NLRB, 313 U.S. 177, 192-93 (1941) (stating that the Board was not "devised" for the "limited function" of correction of private injuries).

11429 U.S.C. $§ 160$ (a). This provision does not preclude the Board's deference to arbitration decisions and settlements that involve the qualification of waivable rights. When considering deference 
Nevertheless, the Court's opinion in Penn Plaza indicates that the Board in appropriate cases could take into account arbitration decisions in its adjudication even of claims involving non-waivable rights. The Penn Plaza Court emphatically retracted the "broad dicta" in its earlier decision, Alexander v. Gardner-Denver, "that was highly critical of the use of arbitration for the vindication of statutory antidiscrimination rights." $" 16$ That Gardner-Denver dicta, on which $\mathrm{I}^{117}$ relied in my attempt to define limits on Board deferral, contended that an arbitration process well-suited for the resolution of contractual claims could compromise statutory rights for numerous reasons - including the arbitration process's relative informality, ${ }^{118}$ some arbitrators' lack of legal expertise, ${ }^{119}$ and a union's potential conflict of interest with individual represented employees. ${ }^{120}$ Taking a very different view of arbitration under collective agreements, the Penn Plaza Court treated such arbitration as comparable to the other forms of arbitration it had found capable of treating both "factual and legal complexities," and thus an acceptable substitute for a judicial forum for private rights of action. ${ }^{121}$

The Board, even in cases involving non-waivable rights, thus should have the discretion to find an arbitration process to have offered an acceptable substitute for its own administrative processes under certain conditions. First, the Board must not accept an arbitrator's incorrect application or interpretation of the meaning of a non-waivable statutory right. The Board's "palpably wrong" or "clearly repugnant" standards accept some degree of compromise of substantive law and thus are not appropriate for deferral to an arbitrator's use of statutory law in cases involving non-

\footnotetext{
in a case involving waivable rights, the Board can treat the arbitration decision or settlement as a modification of the substantive rights upon which the unfair labor practices are based, without compromising its processes for the prevention or remediation of such practices. As explained in text, the Board, by contrast, cannot treat arbitration decisions or settlements involving unwaivable rights as substantive qualifications of those rights.

115 See generally 415 U.S. 36 (1974)

116129 S. Ct. 1456, 1469 (2009). The Court in Gardner-Denver had held that a court should not preclude or defer ruling independently on an employee's Title VII race discrimination suit because an arbitrator had ruled that the employee's contested discharge was for just cause, even though the arbitrator could have invoked a provision in the collective bargaining agreement barring race discrimination. 415 U.S. at 59-60. The Penn Plaza Court distinguished Gardner-Denver by stressing that the collective bargaining agreement in the earlier case did not cover statutory claims; the arbitrator in Gardner-Denver thus had the authority only to resolve the employee's contractual claim of race discrimination, not his statutory claim of discrimination. $129 \mathrm{~S}$. Ct. at 1467.

117 See Harper, supra note 8, at 686; see also United Tech. Corp., 268 N.L.R.B. 557, 563 (1984) (Zimmerman, Member, dissenting).

118 See 415 U.S. at 57-58.

119 Id. at 57.

$120 \mathrm{Id}$. at $58 \mathrm{n} .19$.

121 129 S. Ct. at 1471-73.
} 
waivable rights. $^{122}$ In adjudicating a non-waivable statutory claim, the Board may cite the Penn Plaza decision to support acceptance of an arbitrator's factual findings or her interpretation of relevant contractual clauses, but it must decide any issue of statutory interpretation itself without deference.

Second, the Board should not accept an arbitrator's consideration of a factually parallel, but distinct, claim as an adequate substitute for resolution of a claim of deprivation of a non-waivable $\S 7$ right. Since the parties to a collective agreement can substitute a contractual right for a waivable statutory right, the Board may defer its protection of such statutory rights to a collectively bargained arbitration process's protection of factually parallel contractual claims. ${ }^{123}$ Where employees claim deprivation of non-waivable $\S 7$ rights, however, the Board should not accept the substitution of protection of contractual rights. Neither Judge Edwards's theory, which is limited to waivable statutory rights, nor Penn Plaza, which does not extend to acceptance of the compromise of a substantive right, supports such a substitution.

Third, the arbitration process must have resulted in a decision after an adjudication that the Board deems to have been full and fair. Just as grievance settlement negotiations are not a substitute for a judicial forum, ${ }^{124}$ they are not a substitute for Board adjudication. Similarly, the Board must be convinced that the arbitration process has been fully and effectively utilized by the union or the employee before deferring the exercise of its public responsibilities even on the resolution of factual issues. ${ }^{125}$ The Board can sensibly claim that the preservation of scarce public resources justifies reliance on alternative private processes for the resolution of factual disputes only when it can be confident that those private processes are fair and effective.

Fourth, the Board must be convinced that the union as well as the arbitrator knew that the arbitration process could influence the Board's protection of non-waivable $\S 7$ rights. This is necessary to assure that the parties and the arbitrator treated the arbitration process as a potential substitute for the Board's public processes. The assignment to arbitration of the protec-

122 Under Judge Edwards's theory, these standards are unnecessary in cases where the parties have authority to compromise potentially relevant statutory rights, such as rights to engage in economic strikes. See supra text accompanying notes 32-36.

123 See supra text accompanying notes 39-41.

124 See supra text accompanying note 105.

125 See supra text accompanying notes 106-07. 
tion of such statutory rights thus must be "clear and unmistakable.", In contrast to its role in the implied waiver of $\S 7$ rights under Judge Edwards's theory, ${ }^{127}$ a broad arbitration clause that does not expressly cover all $\S 7$-based grievances should not be the basis for the Board's deferral to even the factual findings in a clear arbitration decision on claims of deprivation of non-waivable $\S 7$ rights.

All of these conditions also should be taken into account by the Board before deferring consideration of a claim of deprivation of non-waivable rights to an uncompleted arbitration process. The Board should defer such a case only after determining that doing so is unlikely to compromise substantive rights and that the union has clearly and unmistakably agreed to have the case arbitrated. The Board thus must be fully satisfied the CollyerUnited Technologies standards ${ }^{128}$ are met in all respects, including the arbitration clause clearly covering the dispute and the dispute being well suited to arbitration. Furthermore, since delay also can lead to a compromise of rights, the Board must be convinced that deferral to the arbitral process will more efficiently and quickly settle the case because the issues are primarily ones of fact rather than statutory interpretation.

\section{CONCLUSION}

The Supreme Court's decision in Penn Plaza provides an appropriate impetus for the Board to reevaluate under a theory of union waiver the relevance of arbitration to the Board's adjudication of unfair labor practice charges. That reevaluation must appreciate, however, that the Penn Plaza decision accepted arbitration only as an alternative to a judicial forum for a private right of action. The decision did not warrant the waiver of public processes for protection of statutory rights ${ }^{129}$ or the waiver of particular underlying substantive rights. ${ }^{130}$ The decision's analysis therefore did not provide direct support for and should not be merged with a waiver justification for mandatory Board deferral to arbitration as Judge Edwards urged. The Board's reevaluation of its deferral doctrine should take into account both Penn Plaza and Judge Edwards's waiver theory, but should do so separately by distinguishing carefully between the treatment of charges claiming the deprivation of waivable $\S 7$ rights subject to union control or waiver and

126 Cf. Wright v. Univ. Mar. Serv. Corp., 525 U.S. 70, 82 (1998) (union waiver of judicial forum to vindicate statutory right must be "clear and unmistakable"; general broad arbitration clause not sufficient).

127 See supra text accompanying notes 21-29.

128 See supra text accompanying notes 42-44.

129 See supra text accompanying notes 109-11.

130 See supra text accompanying notes 104-07. 
those charges claiming deprivation of $\S 7$ rights that a union cannot waive. The Board's distinction of waivable from non-waivable $\S 7$ rights should be guided by the Court's decisions in Magnavox and Metropolitan Edison. ${ }^{131}$

The Board thus should treat employee concerted action in support of the continuation of an incumbent union or incumbent union leadership as it treats concerted action in opposition to such incumbency; neither type of action should be subject to union waiver. ${ }^{132}$

Where an unfair labor practice complaint alleges that an action deprived represented employees only of waivable $\S 7$ rights, and not any non-waivable rights, the Board should defer to a fair and regular arbitration award or settlement that clearly and unmistakably authorized the action. As long as the complaint does not concern non-waivable rights, the Board should not decline to defer because the award or settlement agreement interpreted the underlying collective agreement in conflict with Board doctrine or otherwise expressed an understanding of the law different from that which the Board would apply in the absence of deference. The Board should take into account any law cited in the award or the settlement or the facts considered in the arbitration process only for the limited purpose of determining whether the award or settlement authorized the challenged action. As explained above, in some cases an award or settlement may only determine that the contract did not prohibit the action, without clearly and unmistakably authorizing the action. ${ }^{133}$ In such cases, the award or settlement does not modify or otherwise waive the statutory right and thus does not decide the statutory issue. Most arbitration awards or settlements, however, are intended to authorize a challenged action, not just to preserve it from a contractual challenge.

The Board should not defer a complaint alleging the deprivation of even waivable statutory rights to an arbitration award or settlement authorizing the deprivation if the Board has reason to believe that the union's agreement to the authorization was in breach of its duty of fair representation. As Judge Edwards recognizes, ${ }^{134}$ such a breach invalidates the union's authorization of any waiver of a represented employee's $\S 7$ right. As Judge Edwards does not acknowledge, ${ }^{135}$ however, the Board's current conditioning of deference on arbitration proceedings being "fair and regular" helps ensure that a union has not used an arbitration-based waiver opportunisti11

131 And perhaps also by my attempts to elaborate the Magnavox decision. See supra notes 8 and

132 See supra text accompanying notes $87-92$

133 See supra text accompanying notes 64-69.

134 See Edwards, supra note 19, at 30.

135 See supra text accompanying notes 73-82. 
cally for unprincipled or discriminatory ends, rather than in some good faith service of the aggregate interest of the bargaining unit. The Board thus should continue to use its "fair and regular" standard for deference as a rigorous protection against union abuse of its authority to waive certain $\S 7$ rights. The Board should have greater discretion to deny deferral because of concern about a union's conflict of interests or unprincipled decision making than it does to find a breach of a duty of fair representation because the denial of deferral, unlike a breach of the duty, cannot alone threaten union control over the allocation of limited treasuries. ${ }^{136}$

The Board, even when adjudicating claims of deprivation of nonwaivable $\S 7$ rights, also should have limited discretion to defer to the findings of fact and contractual interpretations contained in arbitration awards rendered in response to fully and fairly litigated contractual grievances. The Board should exercise this discretion only in cases in which the union's acceptance of the arbitration process as an alternative to Board's public processes is clear and unmistakable. Moreover, the Board's discretion in cases involving non-waivable rights should not extend to deference to any interpretations of statutory law that vary to any degree from the interpretations that would be given by the Board. Because deference to an arbitrator's interpretation of relevant statutory law constitutes acceptance of the union's delegation to an arbitrator of authority to modify substantive rights, the Board can defer only to arbitral statutory interpretations or modifications involving $\S 7$ rights under the union's control.

136 See supra note 84. 